ACTA UNIVERSITATIS LODZIENSIS

FOLIA LITTERARIA POLONICA 1(39) 2017

http://dx.doi.org/10.18778/1505-9057.39.16

Monika Milewska*

\title{
Moja podróż na Księżyc
}

Na początku muszę się wytłumaczyć z tekstu, który mają Państwo przed oczami. Jestem antropologiem historii i całe życie analizuję przeróżne teksty kultury, najczęściej o propagandowym lub politycznym charakterze. Po raz pierwszy będę pisać tekst o własnym tekście. Poprosiła mnie o to w listopadzie 2015 roku Osoba, której się nie odmawia - Prof. Elżbieta Pleszkun-Olejniczakowa. I Jej wolą było, aby tekst ten nosił tytuł Moja podróż na Księżyc. Nie mogłam powiedzieć: nie. To w końcu Pani Elżbieta zabrała mnie na Księżyc owego galowego wieczoru 29 czerwca 2015 roku, gdy - z Jej werdyktu - pozbawiona ciążenia stałam na scenie hotelu Sheraton jako laureatka Grand Prix Festiwalu „Dwa Teatry” w Sopocie.

Muszę więc teraz, zgodnie z Jej wolą, opowiedzieć, ,jak powstała Podróż”. Czuję się jak archeolog, który z zatartych wspomnień, niekompletnych e-maili i rozsianych po Sieci artykułów, próbuje złożyć jak najwierniejszą całość. Wrogiem archeologa jest czas. Moja przygoda z tekstem rozpoczęła się dwanaście lat temu, muszę więc głęboko grzebać w pamięci - materii sypkiej jak piasek, a i tak kilku elementów tej historii nie będę nigdy pewna. Nie potrafię na przykład przypomnieć sobie momentu, w którym postanowiłam napisać sztukę o Mélièsie. Pozostało we mnie tylko niejasne, półsenne wspomnienie peronu warszawskiego metra. Czy to tam zrodził się pomysł, by zetknąć dwóch pionierów francuskiego kina na jednym z paryskich dworców? A może, czekając na metro, mierzyłam się tylko z wymyśloną już fabułą? Albo opowiadałam ją jednej z moich przyjaciółek? Nie wiem i brak mi jakichkolwiek źródeł pisanych, aby ten ważny - pewnie tylko dla mnie - szczegół ustalić.

Jednego jestem pewna. Na początku była śmierć. Śmierć u narodzin kina - tak był zatytułowany artykuł, który wiosną 2004 roku pisałam na zamówienie „Kwartalnika Filmowego"1. Przyglądając się opisom pierwszych, jednominutowych jeszcze filmów historycznych, ze zdumieniem zauważyłam, że są one najczęściej poświęcone śmierci. Śmierci Marata, Robespierre’a, księcia Gwizjusza,

\footnotetext{
* Dr, e-mail: monikamilewska@yahoo.com; Uniwersytet Gdański, Instytut Archeologii i Etnologii; 80-851 Gdańsk, ul. Bielańska 5.

${ }^{1}$ M. Milewska, Śmierć u narodzin kina, „Kwartalnik Filmowy” 2004, nr 45, s. 190-196.
} 
Chrystusa. Medium wynalezione po to, by utrwalać życie - z lubością pokazywało śmierć. Zaintrygowana tym fenomenem zaczęłam zgłębiać historię początków kinematografii ${ }^{2}$. W moich lekturach wciąż przewijała się jedna, coraz bliższa i bliższa mi postać - Wielki Mag Kina - Georges Méliès. Iluzjonista i pierwszy artysta filmowy, ktoś, o kim Apollinaire mawiał, że jego fachem jest „zaczarowywanie pospolitej materii”' . Niezwykła była nie tylko jego sztuka, ale i los - autor pięciuset filmów rozpowszechnianych na całym świecie, wierny do końca swojej sztuce, bankrutuje i - w geście rozpaczy - niszczy cały swój dorobek, a potem przez lata pracuje w dworcowym sklepiku z zabawkami. Ten ostatni element jego życiorysu był szczególnie inspirujący dla mnie jako autorki sztuk lalkowych. Wkrótce byłam pewna, że chcę poświęcić mu moją kolejną sztukę pt. Mag. Los mi sprzyjał. W 2005 roku na napisanie dramatu uzyskałam półroczne stypendium Ministra Kultury. Wtedy też Fundacja na rzecz Nauki Polskiej przyznała mi trzymiesięczne stypendium na kwerendę w Paryżu związaną z przygotowywaną przeze mnie książką o kulcie jednostki ${ }^{4}$. Przy okazji mogłam zbierać materiały do sztuki o Mélièsie.

Utwór był gotowy w styczniu 2006 roku. Oto jego krótkie streszczenie:

Jest początek lat trzydziestych dwudziestego wieku. Na jednym z paryskich dworców siedemdziesięcioletni Ludwik Lumière rozpoznaje w sprzedawcy zabawek swojego dawnego rywala z branży filmowej, wielkiego maga kina G. Mélièsa. Ich wypełniona wspomnieniami i sporem o istotę sztuki rozmowa kończy się zakładem. Ludwik Lumière ma zostać producentem ostatniego filmu Mélièsa. Jeżeli to dzieło zachwyci znużonego filmami ojca kinematografii, Lumière podaruje Mélièsowi swą pierwszą kamerę, której odmówił mu 35 lat wcześniej. W drugiej, krótkiej odsłonie następuje prezentacja gotowego już filmu. Na ekranie Méliès - pod bacznym okiem Księżyca - zawija się w białą szarfę, niczym w kokon. Po chwili kokon pęka i wyłania się z niego uskrzydlony młodzieniec. Lumière jest zawiedziony seansem i ogłasza klęskę wypalonego już widocznie Maga. Gdy odwraca głowę, widzi, że zamiast starego Mélièsa z fotela wstaje młodzieniec. Zrzuca ciężki płaszcz, rozwija białe skrzydła motyla i odchodzi w księżycową noc. Utwór jest próbą zderzenia dwóch postaw: racjonalizmu wynalazcy i idealizmu artysty. Mówi też o nadziei na nieśmiertelność, jaką daje nam sztuka.

Ten nieduży objętościowo dramat napisałam z myślą o bardzo konkretnej scenie: Teatrze Atelier, dziesięć lat wcześniej zbudowanym na sopockim piasku przez niezwykłego przybysza z Niemiec, André Hübnera-Ochodlo. Był to jeden z dwóch

${ }^{2}$ Efektem tego był m.in. mój cykl felietonów radiowych „W starym kinie” nadawany w maju 2004 r. na antenie II Programu Polskiego Radia w audycji „Słowo na dzień”.

${ }^{3}$ G. Franju, Georges Méliès, [w:] Un siècle en courts 1895-1915, t. 1, Wydawnictwo Sauve Qui Peut Le Court Métrage, Clermont-Ferrand 1996, s. 43.

${ }^{4}$ Wyszła drukiem jako Bogowie u władzy. Od Aleksandra Wielkiego do Kim Dzong Ila: antropologiczne studium mitów boskiego władcy, Wydawnictwo Słowo/Obraz Terytoria, Gdańsk 2012. 
przybytków Melpomeny, które w pierwszej połowie lat dziewięćdziesiątych zawładnęły moją wyobraźnią. Pierwszy był Teatr Witkacego w Zakopanem, w którym po raz pierwszy odkryłam Wielki Teatr Świata. Pod Tatrami kształtowała się moja wrażliwość, pasja i zamiłowanie do „wąchania” scenicznego kurzu. Gdy skończyły się moje studenckie wyprawy do Witkacego, coś z tamtego klimatu odnalazłam blisko domu, na samym brzegu morza. Otwarty w 1994 roku, w dawnej stolarni sopockiego Grand Hotelu, Teatr Atelier był bardziej ascetyczny, mniej optymistyczny w przesłaniu, z cieniem Holocaustu zawisłym nad malutką scenką. Ceniłam go jednak za wysokiej klasy aktorstwo, świetne aranżacje muzyczne, niezapomniane, przebojowe piosenki precyzyjnie inkrustowane w materię spektaklu. W swoim entuzjazmie wobec estetyki Teatru Atelier nie byłam jedyna. Pokochała ten teatr sama Agnieszka Osiecka i to tak bardzo, że nie mogąc się z nim rozstać nawet po śmierci, została jego patronką. Ta mała scenka w plażowym baraku oferowała coś jeszcze: najniezwyklejszą scenografię świata. Drewniane wrota $\mathrm{w}$ tyle sceny rozchylały się, otwierając nową, sublunarną przestrzeń. Ochodlo chętnie wykorzystywał ten efekt w zakończeniach swoich spektakli. Postaci dramatu wychodziły ze sceny w noc, ku szumiącemu morzu i ku - zawieszonemu na niebie przez Największego ze scenografów - Księżycowi. To była prawdziwa magia teatru, która nie mogła pozostawić mnie obojętną5.

Drugą pasją Ochodlo było niewątpliwie kino. Dowodem na to choćby wyreżyserowany przez niego Szary Aniot Moritza Rinkego z niezapomnianą Joanną Bogacką w roli Marleny Dietrich. Większość spektakli wzbogacona była o projekcje wideo, które pozwalały rozszerzyć kameralne rozmiary sceny. Nie pamiętam, czy ta technika została też zastosowana podczas premiery Darcia pierza, ostatniej sztuki Osieckiej, wystawionej przez Ochodlo w 1998 roku. Pozostały mi tylko w pamięci przejmujące role Teresy Budzisz-Krzyżanowskiej i Marka Richtera, unoszące się nad sceną pierze i chropowaty tekst, z którego przebijał „ból niespełnionego do końca apetytu na istnienie" ${ }^{" 6}$. Szczególne wrażenie zrobiło na mnie „pęknięcie” tekstu: długi pierwszy akt, a po nim krótkie, nieoczekiwane zakończenie. Zafascynowała mnie ta struktura, gdyż łamała ona wszystkie moje dotychczasowe przyzwyczajenia. Wychowana na dwudziestu jeden punktach propagowanych niegdyś na warsztatach pisania dramatu przez mojego Mistrza, Macieja Wojtyszkę, uwierzyłam [nie bez młodzieńczego „wierzgania”] i dotąd wierzę w sens tzw. żelaznej konstrukcji - i tęsknię za takim teatrem, choć właściwie sama

${ }^{5}$ Podobnie pisała popularna trójmiejska recenzentka, Ewa Moskalówna, w trzecim sezonie istnienia teatru: „Barak przy plaży stal się magicznym miejscem. Składają się na to scenografia, która przemienia brzydotę i tandetność miejsca w inne, dziwne piękno, widok plaży i morza u wejścia. Ale przed wszystkim - aura, klimat psychiczny”, „Głos Wybrzeża”, cyt. za: http://www. teatratelier.sopot.pl/ [dostęp: 24.06.2016].

${ }^{6}$ J. Sieradzki, Polityka, cyt. za: http://www.teatratelier.sopot.pl/show_sztuki_szczegoly. php?id=94 [dostęp: 24.06.2016]. 
nie wiem, czy dziś jeszcze - po tylu odmiennych, często nieakceptowanych przeze mnie doświadczeniach teatralnych - byłabym wdzięcznym jego odbiorcą. Tę strukturę, ten taneczny krok: „długi krótki” wykorzystam po latach w Podróży.

Inspirujący byli też dla mnie aktorzy występujący na deskach Teatru Atelier. Zwłaszcza Ryszard Ronczewski, legendarny biały Pierrot/Arlekin z Cyrku Rodziny Afanasjeff. Widziałam go w wyobraźni jako mojego Maga, który w zakończeniu - odmłodzony przez swojego zmiennika - rozwija białe skrzydła motyla i odchodzi w głąb sopockiej plaży. Myślę, że widzowie, którzy pamiętają film Jerzego Afanasjewa Biate zwierzęta z 1960 roku byliby pod wrażeniem tego obrazu.

Miałam więc już tekst, obsadę i scenografię. Wystarczyło tylko wysłać e-mail do Teatru Atelier. Dostałam nań następującą odpowiedź:

Szanowna Pani Moniko,

serdecznie dziękujemy za przesłanie nam swojej sztuki i tym samym obdarzenie nas tak dużym zaufaniem. Na chwilę obecną wystawienie sztuki „Mag” na deskach naszego teatru nie jest możliwe. Zmienia się forma Lata Teatralnego Sopot, w tym roku nie wystawiamy żadnej sztuki dramatycznej. Prezentować będziemy tylko spektakle muzyczne. Pani sztukę zachowujemy jednak w naszym archiwum.

Z poważaniem,

Daria E. Kulesza

Teatr Atelier im. Agnieszki Osieckiej

Teatr zwinął skrzydła. A Méliès razem z nim. Sztukę musiałam zdjąć z afisza, który już rozklejałam w wyobraźni wokół wymarzonej sceny. Coś z nią trzeba było zrobić. Zaraz po napisaniu posłałam ją do „Dialogu”. Posłałam może nawet trochę przedwcześnie, gdy nie utarły się jeszcze wszystkie dialogi, a niektóre monologi brzmiały jak esej. W oczekiwaniu na odpowiedź wysłałam ją więc jeszcze raz - już w poprawionej wersji. W kwietniu dostałam wiadomość z decyzją: „Niestety, to dalej jest nie dla nas” $i$ adres do producentki spektakli telewizyjnych, którą mój tekst mógłby zainteresować. Nie zainteresował. Za to, ku mojej radości, w lipcowym numerze „Dialogu”, Jacek Sieradzki zamieścił rzetelne i życzliwe omówienie Maga. Podsumował mój utwór w następujący sposób: „Zadziwiająca jest ta miniaturka, na poły scena z podręcznika historii filmu, na poły alegoryczna przypowiastka o istocie sztuki i roli, jaką spełnia w niej wyobraźnia"7.

Wysłałam tę miniaturkę do radia. Nie dostałam odpowiedzi. Wysłałam na konkurs słuchowisk - bez echa. Po latach dowiedziałam się, że sztuka krążyła

\footnotetext{
7 J. Sieradzki, Sztuki przeczytane: Monika Milewska, „,Mag”, „Dialog” 2006, nr 7, s. 195.
} 
po Teatrze Polskiego Radia, ale nikt z reżyserów nie miał na nią pomysłu. Rozsyłałam tekst po znanych mi dobrze teatrach lalkowych [w końcu akcja dzieje się w sklepiku z zabawkami, a sztuka ma walory edukacyjne $\left.{ }^{8}\right]$. Nikt nie podjął wyzwania. Jesienią 2006 roku Elżbieta Manthey, szefowa Agencji ADiT, zorganizowała czytanie fragmentów Maga w ramach Biesiady Literackiej w Salonie Warszawskim prowadzonym przez Stowarzyszenie Pisarzy Polskich. Po czytaniu zapachniało naftaliną. „To taki Szaniawski” - powiedział mi jeden z aktorów i chyba nie był to komplement. Nie komplementował mnie też jeden z zaprzyjaźnionych jurorów na warsztatach dramaturgicznych w Zaniemyślu. Jego zdaniem postaciom brakowało życia, a sporowi między nimi - prawdziwego napięcia. Coraz niżej spuszczałam głowę...

Był tylko jeden radosny dzień. W 2006 roku podczas Festiwalu „Dwa Teatry”, zachwycona Juliuszem Cezarem Jana Englerta odważyłam się podejść do jego reżysera i odtwórcy. Wręczyłam mu Maga z myślą o scenie kameralnej Teatru Narodowego i - być może - jego reżyserii. Bez żadnych jednak nadziei. Gdy w pofestiwalowy wtorek maszerowałam z PAN-owską ,wycieczką zakładową" do Stawisk, zadzwoniła komórka. W słuchawce usłyszałam głos Englerta, który przeczytał moją sztukę w drodze powrotnej ze zwycięskiego dla siebie festiwalu. Stwierdził, że jest ona jednym z jaśniejszych punktów najnowszej dramaturgii, którą z racji zajmowanego stanowiska musi teraz w dużych ilościach pochłaniać. Dodał parę ciepłych słów o tekście [których z wrażenia nie zapamiętałam], ale i wyraził obawę, że jest on za krótki na pełnospektaklowe przedstawienie. Niczego mi też nie obiecał. Pełna nowego zapału powróciłam do pracy nad sztuką. Wydłużyłam ją i tchnęłam więcej życia w bohaterów. Wiedziałam już jednak, że to życie $i$ te coraz bardziej emocjonalne i ważkie spory Méliès i Lumière wieść będą musieli przez długie lata w szufladzie.

Po latach okazało się, że droga na Księżyc prowadzi przez Wyspę Słońca. W 2010 roku prezes Gdańskiego Oddziału SPP poprosiła mnie, abym jako sekretarz oddziału wyjątkowo pojechała zamiast niej na posiedzenie Zarządu Głównego w stolicy. Nolens volens powlokłam się rozpaczliwie wówczas wolnym ekspresem z Gdańska do Warszawy, plując sobie po drodze w brodę za brak asertywności. Na zarządzie omawiano akurat sprawy współpracy SPP z domem pracy twórczej na Rodos. Odpowiedzialny za tę współpracę Jacek Moskwa z miejsca wytypował mnie jako kandydatkę do pobytu na wyspie Heliosa. We wrześniu 2011 roku wyjechałam, a właściwie wypłynęłam na kilkunastodniowe stypendium. Już na miejscu, w Centrum Pisarzy i Tłumaczy w Rodos, ktoś powiedział mi, że w pobliskim miasteczku mieszka zaprzyjaźniona z centrum Polka,

8 „Sztuka Moniki Milewskiej ma ogromny walor edukacyjny, z powodzeniem można ją traktować jako doskonałą, pogłębioną lekcję na temat początków kina" - pisała Joanna Olczakówna w omówieniu sztuki na stronie Agencji Dramatu i Teatru ADiT, http://adit.art.pl/sztuki/podroz-na-ksiezyc [dostęp: 26.06.2016]. 
Barbara Grzegorzewska. Tę niezwykle cenioną tłumaczkę francuskich sztuk i bajek udało mi się poznać dwanaście lat wcześniej na stypendium naukowym w Paryżu, gdzie w słynnej polskiej kuchni na Lamandé podpowiadała mi, na jakie paryskie spektakle powinnam się koniecznie wybrać. Poczułam, że muszę odnowić tę znajomość. Udało się. Barbara chyba nie pamiętała mnie z moich doktoranckich czasów, ale mimo to potraktowała mnie bardzo serdecznie, pokazując zabytki swojego miasteczka i własny apartament. Nawiązałyśmy kontakt, po powrocie przesłałam jej kilka moich sztuk.

Na początku lata 2013 roku dowiedziałam się, że Barbara - jako wiceprzewodnicząca Sekcji Autorów Dzieł Dramatycznych ZAiKS - zgłosiła mnie do konkursu zamkniętego zorganizowanego z okazji 85-lecia nadania pierwszego oryginalnego słuchowiska polskiego oraz 95-lecia Stowarzyszenia Autorów ZAiKS. Było to dla mnie duże wyróżnienie, więc z radością przystąpiłam do konkursu. Wpadłam już nawet na pomysł pełnej napięcia psychodramy rozgrywającej się między dwoma sobowtórami Stalina, ale gdy upłynęło kilka wypełnionych po brzegi różnymi zajęciami tygodni, zdałam sobie sprawę, że nie zdążę stworzyć nowego tekstu od podstaw. Zajrzałam do szuflady. Leżał tam nigdzie dotąd niewystawiany, nigdzie niepublikowany, nikomu niepotrzebny Mag. Przeczytałam go świeżym okiem i od razu zobaczyłam, co należy zmienić. Od kilku lat byłam szczęśliwą posiadaczką Własnego Mieszkania Bez Telewizora. Zupełnie świadomie wybrałam sobie za przyjaciela Radio. Wiecznie rozgadany radioodbiornik stał się drugim, pełnoprawnym mieszkańcem mojego M-5. Przez lata naszego związku wiele się o nim dowiedziałam, lepiej poznałam jego naturę i przyzwyczajenia. Wiedziałam już, że Mag jako słuchowisko jest przegadany i że brak mu prawdziwie radiowej magii. Dwóch starszych panów to dla Teatru Wyobraźni za mało, nawet jeśli ci panowie są ojcami światowej kinematografii i spierają się o istotę sztuki. Tak, to zdecydowanie za mało dla naszej dzisiejszej pokawałkowanej, rozbitej przez nadmiar bodźców percepcji. Nie chciałam tworzyć kolejnej radiowej dyskusji w paśmie „Kultura”. Dodałam więc dźwięki i głosy z przeszłości. Retrospekcje - ten filmowy par excellence chwyt - pasowały jak ulał do opowieści o początkach kina. Tekst naprawdę ożył - widziałam to już na papierze. Odcięłam się też od przeszłości, zmieniając tytuł utworu - tak jakby zmiana imienia mogła w magiczny sposób odmienić jego los. Na pewno zaś pomogła dotrzymać wymogów regulaminowych konkursu, do których należała anonimowość tekstu - sztukę Mag łatwo było powiązać z moim nazwiskiem. Podróż na Księżyc kojarzyła się tylko z nazwiskiem Mélièsa.

W grudniu 2013 roku zadzwonił telefon z II Programu Polskiego Radia. „Zdobyła pani drugie miejsce w konkursie na słuchowisko radiowe. Ex aequo z Małgorzatą Sikorską-Miszczuk". Podczas uroczystego rozdania nagród czułam się trochę jak mój bohater wyciągnięty po latach ze swego sklepiku z zabawkami w rażące światło fleszy i to jemu złożyłam hołd w mojej krótkiej przemowie na 
scenie. Jak w dziesiątkach, setkach jego filmów, zaszła metamorfoza - traktowana do tej pory przez wszystkich jak Kopciuszek sztuka zaczęła budzić zachwyt. Chwalono przede wszystkim mój ,przewrotny” pomysł, by stworzyć słuchowisko o kinie niemym9 . Pomysł, jak już wiemy, nie był mój. Kto zań zatem odpowiada? Przypadek, a może uśmiechający się przekornie z jakiejś chmurki Mag Kina? Nagroda otwarła mi radiowe drzwi. Dzięki niej mogłam zaprezentować w Dwójce moje wiersze, zostałam też zaproszona do poświęconej Gdańskowi audycji „Miasta pisarzy”, gdzie na antenie zobowiązałam się do napisania „gdańskiej” powieści. Powieść jest już gotowa. Zajęła w szufladzie miejsce dobrze wymoszczone przez Mélièsa.

Przyszedł czas realizacji słuchowiska w radiowej Dwójce. Ostateczny wybór padł na Annę Wieczur-Bluszcz. Gdy zadzwoniła do mnie po raz pierwszy, przechadzałam się właśnie w świetle księżyca. Od razu nawiązałyśmy świetny kontakt - widziałam, że reżyserka doskonale czuje i rozumie mój tekst. Podobnie jak ja wychowała się na programach „W starym kinie”, i jak nikt inny łączyła w sobie pasję reżysera filmowego i twórcy słuchowisk. Mój Méliès nie mógł trafić w lepsze ręce. Przy tym doskonale nam się rozmawiało i jeszcze lepiej pracowało nad tekstem. A praca była konieczna, bo tym razem słuchowisko okazało się... za długie. Walczyłyśmy telefonicznie o każdą sekundę. Zazwyczaj denerwują mnie skreślenia czynione obcą ręką, ale tym razem zgadzałam się z każdą niemal propozycją, tak jakby każda była moją własną - z tak wielkim pietyzmem i wyczuciem reżyserka wynajdywała w tekście wyrazy niekonieczne i zdania nie dość nośne - takie, bez których nie zawali się konstrukcja dramatu. Poprosiła mnie też o przetłumaczenie komunikatów dworcowych na język francuski z myślą o uroczym głosie Elisabeth Duda i prawdziwie paryskim nastroju słuchowiska. Wyrzuciła za to - i słusznie - tetrycznego Słuchacza, dzwoniącego do radia na początku utworu i domagającego się sprostowania ze strony Narratora, który pomylił nazwy stołecznych dworców $^{10}$. Nic nie miało prawa zakłócać magicznej, paryskiej wigilijnej opowieści.

W którejś z telefonicznych rozmów reżyserka przedstawiła mi swój plan obsady. Wtedy po raz pierwszy delikatnie zaprotestowałam: „Englert i Radziwiłowicz? Przecież oni są za młodzi!”. „Sprawdziłam - są dokładnie w tym samym

${ }^{9}$ A. Jazgarska, Georges Méliès w ,teatrze wyobraźni”, http://teatralny.pl/rozmowy/georges-melies-w-teatrze-wyobrazni,226.html [dostęp 27.06.2016].

${ }^{10}$ Problem dworców w moim słuchowisku to materiał na osobną opowieść. W rzeczywistości Méliès sprzedawał swoje zabawki na dworcu Montparnasse, ale mojego Lumière’a postanowiłam wysłać na święta do rodzinnego Lyonu, dokąd z Paryża można dojechać jedynie z dworca Gare de Lyon. Dlatego zdecydowałam się umieścić akcję na fikcyjnym paryskim dworcu. Gdy przed pierwszą emisją słuchowiska tłumaczyłam na antenie zawiłości topografii dworców Paryża, któryś z redaktorów przetłumaczył moje słowa: „dworzec lyoński” na „dworzec w Lyonie” i uczynił z niego miejsce akcji sztuki. Ten błąd pokutuje teraz w licznych opisach Podróży na Księżyc. Por. http://www.polskieradio.pl/8/295/Artykul/1469104,Podroz-na-ksiezyc-Grand-Prix-Dwoch-Teatrow-dla-sluchowiska-Dwojki [dostęp: 27.06.2016]. 
wieku, co Twoi bohaterowie". No tak, uwielbiani aktorzy mojego dzieciństwa zawsze pozostaną dla mnie młodzieńcami. Jak Méliès u końca Podróży.

Wreszcie nadszedł dzień premiery - sobota, piątego kwietnia 2014 roku. W odświętnym stroju zasiadłam z rodzicami przed radioodbiornikiem, tak jak się zasiada na uroczystej premierze filmowej. I ruszyła projekcja. Do naszego maleńkiego kina wjechała potężna lokomotywa z La Ciotat, a potem niewidzialna ręka pokręciła korbką starego projektora i pod naszymi powiekami pojawiły się obrazy ze starych filmów. Ożyły Głosy z przeszłości. I głosy dwóch ojców kinematografii. Jerzy Radziwiłowicz z niezwykłą perfekcją oddawał zapisane przeze mnie ostrożne słowa Lumiére’a, a wiekowy z początku Englert-Méliès młodniał z każdą chwilą, zapalając się na wspomnienie swojej niegdysiejszej sztuki. Jego głos zdawał się coraz bardziej uskrzydlony. Aż do wyciszonego, lirycznego finału, w którym rolę Narratora odegrał Przemek Bluszcz. Jego słowa dopowiadające koniec historii były delikatne jak kroki motyla ${ }^{11}$. Kiedy ucichła końcowa melodia Świateł rampy wstaliśmy i biliśmy brawo jak na prawdziwej premierze filmu ${ }^{12}$. Oklaskiwaliśmy reżyserkę, aktorów i autora perfekcyjnej realizacji akustycznej - Macieja Kuberę. To był niezapomniany seans w starym kinie. Dzięki niemu zrozumiałam, że siłą Podróży na Księżyc jest właśnie zapach naftaliny unoszący się nad kapeluszami dwóch starszych panów. Jej atutem jest to, że jest ona tak świadomie, nieomal prowokacyjnie niemodna. Choć może dziś - dwa lata po premierze - jest modna nieco bardziej? W końcu na naszych oczach idolem polskiej publiczności stał się na nowo Eugeniusz Bodo...

W wieczór poprzedzający rozdanie nagród jubileuszowego XV Festiwalu „Dwa Teatry”, dyrektor Teatru Polskiego Radia, Janusz Kukuła, reżyser moje-

${ }^{11}$ Jego rolę docenił bardzo Janusz Łastowiecki, pisząc w recenzji: „Po gali zakończenia powiedziałem do twórców zwycięskiego słuchowiska, że zawsze byłem przeciwnikiem narratora. Tym razem jednak nie wyobrażam sobie, by to słuchowisko mogło istnieć bez niego. Bluszcz, niezauważalny i nienachalny, sprawnie «wmontowany» przez Kuberę, pełni tu rolę niewidzialnej ręki słuchowiska, która przesuwa kadry w naszej głowie”, http://www.e-teatr.pl/pl/artykuly/205163. html [dostęp: 27.06.2016]. Warto zaznaczyć, że Narrator pojawia się tylko dwukrotnie: na początku i na końcu słuchowiska, jest więc rzeczywiście nienachalny.

${ }^{12} \mathrm{O}$ filmowości Podróży na Księżyc ciekawie pisze Łastowiecki: „Słuchowisko Milewskiej jest filmem w dźwięku. Za pomocą naturalnie wplecionych elementów scenografii radiowej [nieziemska, księżycowa praca Macieja Kubery] słuchacz odkrywa, że rzeczywistość filmowego słuchowiska jest celem samym w sobie, a w finale opowieści, zyskuje osobisty wydźwięk - wręcz antyfilmowy. Kapelusz według tekstu Wiesława Myśliwskiego w reżyserii Waldemara Modestowicza czy Syreni śpiew Jerzego Górzańskiego w reżyserii Jana Warenyci - dwa słuchowiska, które za temat wzięły film, takie właśnie były. Opowiadając obrazami, pokazywały, że te obrazy trzeba wytworzyć w uchu. Projekt teatru wyobraźni jest wciąż możliwy do odnowienia. Trzeba paradoksalnie wrócić do efektu «niewidzialności», by go na nowo uruchomić. Fotocasty, zdjęcia z nagrań, promowanie spektakli radiowych chwytami potentatów telewizyjnych to droga do zatracenia się idei słuchowiska. Milewska z Wieczur-Bluszcz wracają do początków. Czasami trzeba zrobić krok do tyłu, by zobaczyć jak dotrzeć do księżyca", http://www.e-teatr.pl/pl/artykuly/205163.html [dostęp: 27.06.2016]. Również Jacek Wakar w rozmowie ze mną na antenie Dwójki stwierdził, że „słuchowisko to inny rodzaj kina”. 
go debiutanckiego, licealnego jeszcze Savonaroli ${ }^{13}$, szepnął mi, abym założyła nazajutrz ładną sukienkę. „To będą wielkie chwile” - powiedział tajemniczo na tarasie nowego, rozbudowanego Teatru Atelier, na którego scenie tego dnia w radioznawczych referatach wspominano o mojej Podróży. Nie śmiałam zgadywać, co oznaczają słowa dyrektora. Kiedy szłam do domu aleją wzdłuż sopockiej plaży, księżyc był dojrzały jak brzoskwinia w pełni.

Następnego dnia były wywiady i gala w położonym nieopodal Teatru Atelier nowym hotelu Sheraton. To był mój jubileuszowy, piętnasty festiwal. „Dwa Teatry" to moja szkoła teatralna, to moje święto doroczne, na którym przez parę dni mogę obcować z Mistrzami, z których wielu już odeszło, oglądać spektakle, słuchać słuchowisk, napawać się sztuką i wielkim artystycznym światem od rana do wieczora. Zabrakło mnie tylko na jednej edycji - w 2005 roku, gdy zbierałam w Paryżu materiały do sztuki o Mélièsie. Teraz, w zielonej sukience, po raz pierwszy siedziałam na gali jako uczestnik festiwalu, przeżywając festiwalowe katusze. Omijały nas wszystkie nagrody, narastało zwątpienie. Na koniec na scenie pojawił się Prezes Polskiego Radia, Andrzej Siezieniewski, z kopertą, w której tkwiła tajemnica Grand Prix. Powiedział, że być może słuchowisko, które zostanie dziś tą nagrodą wyróżnione, trafi kiedyś do skarbnicy dziedzictwa narodowego. „Jak pięknie powiedziane” - pomyślałam. „Gdyby te słowa mogły dotyczyć mojej sztuki...”. Sen się spełnił. Jury pod przewodnictwem Pani Profesor Elżbiety Pleszkun-Olejniczakowej postanowiło wysłać mnie na Księżyc.

Czy ta droga musiała być aż tak wyboista? Pewnie tak, bo gdyby w tej układance zmienić choć jeden element, całość nie byłaby tak piękna. Gdyby sztuka odniosła wcześniej choćby najmniejszy sukces, moi bohaterowie nie przemówiliby głosem Englerta i Radziwiłowicza. W Podróży na Księżyc Méliès mówi do Lumière'a: „My obaj też będziemy jeszcze żyć za sto, a może dwieście lat, dopóki znajdzie się ktoś, komu będzie się chciało pokręcić korbką projektora, by zobaczyć dwóch niemodnych panów w kapeluszach". Może za sto albo dwieście lat znajdzie się ktoś, komu będzie się chciało przesłać myślą impuls, by odsłuchać te dwa niezwykłe głosy mówiące moim, archaicznym już tekstem w niemodnym a może znowu modnym - słuchowisku.

\section{Bibliografia}

Franju G., Georges Méliès, [w:] Un siècle en courts 1895-1915, t. 1, Wydawnictwo Sauve Qui Peut Le Court Métrage, Clermont-Ferrand 1996.

Milewska M., Bogowie u władzy. Od Aleksandra Wielkiego do Kim Dzong Ila: antropologiczne studium mitów boskiego władcy, Wydawnictwo Słowo/Obraz Terytoria, Gdańsk 2012.

Milewska M., Śmierć u narodzin kina, „Kwartalnik Filmowy” 2004, nr 45, s. 190-196.

Sieradzki J., Sztuki przeczytane: Monika Milewska, ,Mag”, Dialog 2006, nr 7, s. 194-195.

${ }^{13}$ Premiera Savonaroli miała miejsce w 1995 r. na antenie II Programu Polskiego Radia. 


\title{
Netografia
}

Jazgarska A., Georges Méliès w „teatrze wyobraźni”, http://teatralny.pl/rozmowy/georges-melies-w-teatrze-wyobrazni,226.html [dostęp: 27.06.2016].

http://www.teatratelier.sopot.pl/show_sztuki_szczegoly.php?id=94 [dostęp: 24.06.2016].

http://www.polskieradio.pl/8/295/Artykul/1469104,Podroz-na-ksiezyc-Grand-Prix-Dwoch-Teatrow-dla-sluchowiska-Dwojki [dostęp: 27.06.2016].

http://www.teatratelier.sopot.p1/ [dostęp: 24.06.2016].

http://adit.art.pl/sztuki/podroz-na-ksiezyc [dostęp: 26.06.2016].

http://www.e-teatr.pl/pl/artykuly/205163.html [dostęp: 27.06.2016].

\section{Inne źródła}

Milewska M., cykl felietonów radiowych „W starym kinie” nadawany w maju 2004 r. na antenie II Programu Polskiego Radia w audycji „Słowo na dzień”.

\author{
Monika Milewska
}

\section{My journey to the moon}

(Summary)

The article deals with the complicated fates of my radio drama Podróż na Księżyc [Journey to the Moon]. In it, I write about the inspiration I drew from the work on an article about the subject of death in early silent cinema. Researching the beginnings of world cinema, I could not have ignored the figure of Georges Meliès, the great Cinema Magician. I decided to devote a theatre play to him, in which I confronted his idealistic attitude, which led him to ruin, with that of the rational attitude of the father of cinema, Louis Lumière. I wrote the piece about the immortality that art confers with the Teatr Atelier in Sopot in mind. The theatre, though, ceased operating and no other theatre was interested in the text. After several years, a coincidence led to me being invited to participate in an invited competition organised by ZAiKS and the radio station Dwójka. The drama Podróż na Księżyc took second place and was magnificently directed by Anna Wieczur-Bluszcz. The roles of these pioneers of cinema were filled by Jan Englert and Jerzy Radziwiłowicz. In 2015 a jury led by Elżbieta Pleszkun-Olejniczakowa awarded the drama the Grand Prix at the "Dwa Teatry" [Two Theatres] Festival in Sopot.

Keywords: radio drama, Podróż na Księżyc [Journey to the Moon], Meliès, Lumière, silent cinema, "Dwa Teatry" [Two Theatres] Festival. 